\title{
Identification of constructs typifying virtual consumer involvement in product development
}

\author{
Lucelindo Dias Ferreira Junior, Daniel Capaldo Amaral \\ University of São Paulo \\ e-mails: lucelindo@usp.br; amara|@sc.usp.br
}

\begin{abstract}
The subject of virtual consumer involvement in product development has been addressed by different fields of research. The use of different terminologies and concepts, employed by distinct areas, concurs to a fragmented literature lacking in consistency that hinders understanding. This paper identifies key constructs that typify virtual consumer involvement in the field of new product development. To this end, this study conducts an exploratory literature review and identifies seminal and relevant literature on the subject. Then, it identifies and describes seven constructs, e.g., participating entities, motivation mechanisms, and process-supporting tools.
\end{abstract}

Keywords: virtual consumer involvement, consumer involvement, new product development.

\section{Introduction}

Consumer involvement in new product development can significantly contribute to improving the efficacy of the product being developed, thereby promoting innovation (GONZÁLEZ; TOLEDO, 2012). In order to accomplish it, important aspects should be taken into account, e.g., stages in the new product development process in which consumers participate (GRUNER; HOMBURG, 2000), participating consumer's characteristics (THOMKE; von HIPPEL, 2002; LETTL, 2007), organizational infrastructure and support for dialogue (CICCANTELLI; MAGIDSON, 1993; PRAHALAD; RAMASWAMY, 2004; FÜLLER; MATZLER, 2007).

The increase in computer-mediated communication via the Internet has enabled support for real-time multimediarich interactions between consumers and organizations, increasing the interactivity, range, speed, endurance, and flexibility of consumer involvement (SAWHNEY; VERONA; PRANDELLI, 2005). Therefore, it has "provided a realistic understanding of product and integration with consumers' creativity" (FÜLLER; MATZLER, 2007).

The subject of virtual consumer involvement (VCI) in new product development (NPD) is addressed in the literature of various areas, e.g., management science, new product development and collaborative networks. Scholars approach the topic using different terminologies. Moreover, available concepts, methods, and models are fragmented and different areas addressing this subject approach it differently. As a result, there is no consensus about constructs capable of typifying VCI in NPD in general.
This study aims to identify key constructs that typify VCI in NPD from an exploratory review perspective. Identifying these constructs is the first step to understanding and generating an integrated operational definition of VCI in NPD, i.e., a definition consistent with multiple perspectives. This integrated definition would enable a simplified dialogue among the areas involved, based on a shared language that can contribute to a consistent and unified theoretical development of the subject.

\section{Research approach}

An exploratory literature review was conducted so as to identify seminal articles on the subject of VCI in NPD. The following groups of keywords were employed in the searches, either combined or alone: (1) collaborative network, social network, social media; (2) customer-made, crowdsourcing, virtual customer involvement; virtual customer community; (3) new product development, co-creation. Searches were conducted in the following databases: ISI Web of Knowledge, Science Direct, and Google Scholar.

The articles identified in the searches were screened as follows: at first, only titles, abstracts and keywords were read; then, the selected articles were read in their entirety. In order to be selected, the articles had to meet the following criteria: (a) they should provide definitions and terms applicable to the subject of VCI in NPD, and (b) they should provide strategies for virtual consumer involvement, by either indicating methods or describing processes that 
serve this purpose. Articles that did not meet the inclusion criteria were excluded.

Twenty-three potentially useful articles were directly identified in the aforementioned databases. Subsequently, 8 seminal articles were selected for content analysis, from which 12 additional cross-references were obtained. Finally, a content analysis of selected articles allowed the identification of constructs typifying VCI in NPD. Constructs were identified from recurring themes in each description and definition of the virtual consumer involvement phenomenon. This resulted in a preliminary list of constructs, which were grouped under more comprehensive terms expressing their similarity.

The constructs identified were divided into three groups: (1) consumer, (2) organizer, (3) virtual involvement process. The first group, called consumer, is composed of two constructs: (1.1) entity brought into involvement, (1.2) motivation mechanisms. The second group, called organizer, consists of two constructs: (2.1) involvementenabling entity, (2.2) return of involvement. The third group, termed virtual involvement process, comprises three constructs: (3.1) process-enabling tools; (3.2) type of call; (3.3) trigger. Figure 1 presents a summary.

The following sections describe the identified constructs.

\section{Consumer}

\subsection{Entity brought into involvement}

The entity brought into involvement consists of consumers and is defined as those who will be virtually involved in NPD in order to contribute their creativity and ability to solve problems and assess, test, and develop new product ideas (FÜLLER; MATZLER, 2007), i.e., provide input to support the organization's NPD. This entity can be a single individual in dyadic interaction with the organization (HOWE, 2006 apud BRABHAM, 2008) or a group of individuals, whose number, heterogeneity, and type of knowledge should be defined by the VCI organizer (ESTELLÉS-AROLAS; GONZALÉZ-LADRÓN-DEGUEVARA, 2012).

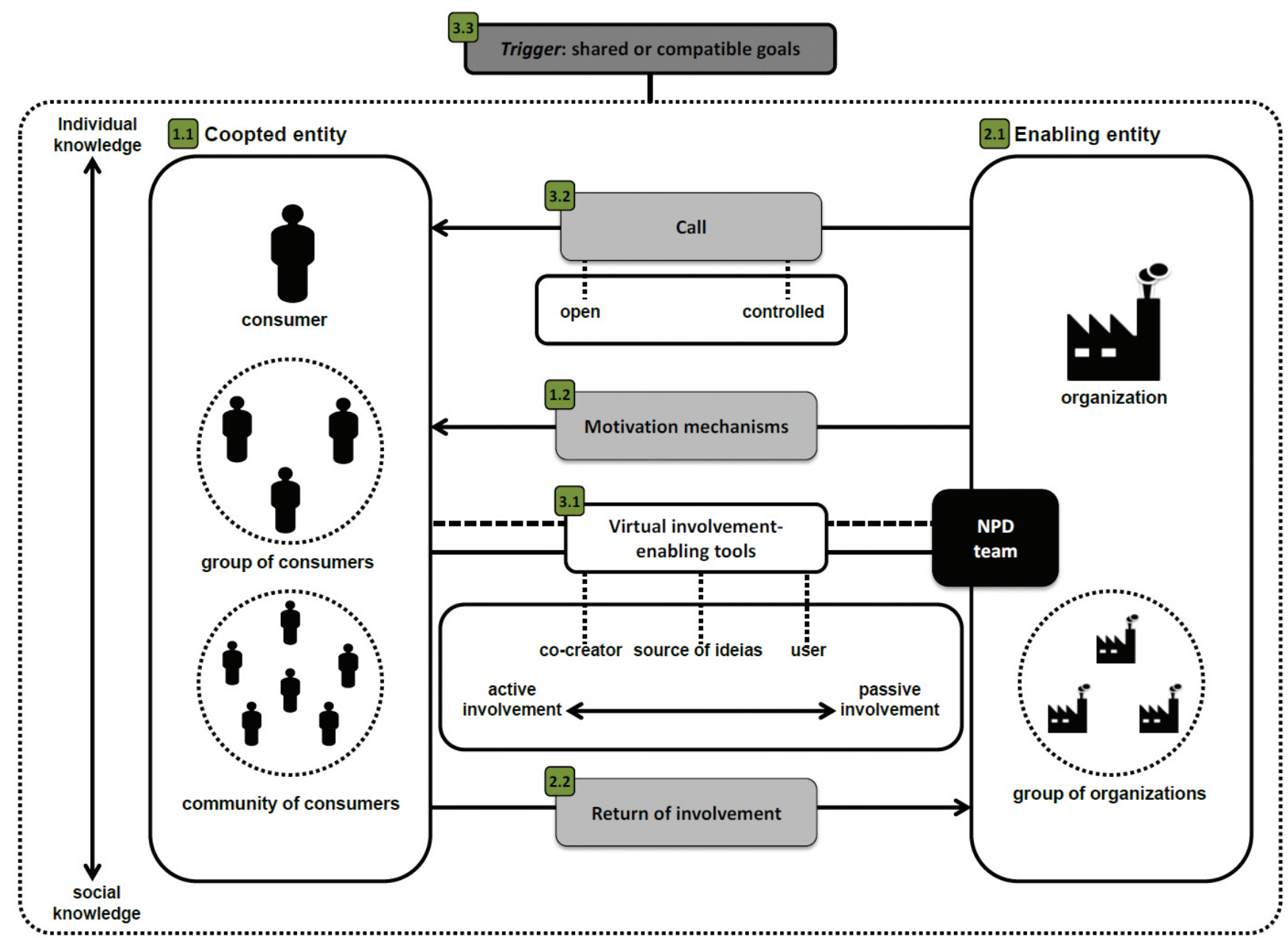

Figure 1. Summary of VCI in NPD. Source: author. 
When grouped, consumers may become virtual communities. A virtual community can be defined as a permanent or temporary grouping of individuals by means of electronic media interacting around a shared interest (PLANT, 2004). In virtual consumer communities, products and services of any given organization can be discussed, analyzed, criticized, and potentially improved (ROMERO; MOLINA, 2011) with users' support of collaboration in the development and implementation of innovations (von HIPPEL, 2005).

The term consumer is referred to in many ways in the literature, e.g., "user" (FÜLLER; MATZLER, 2007), "individuals" or "network of people" (BRABHAM, 2008); "consumer" or "customer" (ROMERO; MOLINA, 2011), and “crowd” (ESTELLÉS-AROLAS; GONZALÉZ-LADRÓNDE-GUEVARA, 2012). Likewise, the concept of virtual communities of consumers is referred to as, for example, "communities of creation" (SAWHNEY; PRANDELLI, 2000), "innovation communities" (von HIPPEL, 2005), "online communities" (FÜLLER; MATZLER, 2007), "user communities" (FRANKE; KEINZ; SCHREIER, 2008), "virtual customer communities" (ROMERO; MOLINA, 2011), and "online product communities" (NAMBISAN; WATT, 2011).

\subsection{Motivation mechanisms}

Motivation mechanisms can be defined as the means by which an organization encourages consumers to participate in and provide input to NPD via virtual involvement tools (ROMERO; MOLINA, 2011). These incentives should be perceived as advantages by users, leading to their virtual involvement (KOHLER et al., 2011) and can be provided either intentionally or unintentionally by the entity that devised the initiative (ESTELLÉS-AROLAS; GONZÁLEZLADRÓN-DE-GUEVARA, 2012).

Four groups of motivation mechanisms were identified (ROHRBECK; STEINHOFF; PERDER, 2010): (1) entertainment and curiosity, (2) social recognition, (3) personal needs and those related to product/service, and (4) financial incentives.

Motivation mechanisms pertaining to entertainment and curiosity refer to incentives deriving from experience gained by using the tool, which can be linked to the use of a new technology (NAMBISAN, 2002), or performing an autotelic/playful/fun task (FÜLLER, 2006; FÜLLER; MATZLER, 2007), exploration of curiosity (FÜLLER, 2006), and searching for new information related to product or innovation (FÜLLER, 2006).

Motivation mechanisms pertaining to social recognition (ESTELLÉS-AROLAS; GONZÁLEZ-LADRÓNDE-GUEVARA, 2012) are those that promote status (NAMBISAN, 2002), sense of belonging and identity related to affiliation to a consumer community (NAMBISAN, 2002), recognition as co-inventor (FÜLLER, 2006; FÜLLER; MATZLER, 2007), same-opinion friendships (FÜLLER, 2006), feeling of altruism and support for community (FÜLLER, 2006), and self-esteem (ESTELLÉS-AROLAS; GONZÁLEZ-LADRÓN-DE-GUEVARA, 2012).

Motivation mechanisms that meet personal needs and those related to product/service, also known as product/ service-related incentives (NAMBISAN, 2002), are those deriving from the possibility of influencing the final product/ service in order to tailor it to personal needs or resolve dissatisfactions (NAMBISAN, 2002; FÜLLER, 2006), apply personal creativity and skills to solve challenging problems (NAMBISAN, 2002; FÜLLER, 2006), and gain experience and acquire knowledge and skills from participation in the development of new products or technologies (NAMBISAN, 2002; FÜLLER, 2006; ESTELLÉS-AROLAS; GONZÁLEZ-LADRÓN-DEGUEVARA, 2012).

Lastly, financial incentives are those that promote VCI by offering advantages such as free gifts (FÜLLER, 2006; ROMERO; MOLINA, 2011), bonus points (FÜLLER, 2006), sweepstakes or immediate monetary compensation (FÜLLER, 2006), sharing of royalties or intellectual property (ROMERO; MOLINA, 2011), and rewards of an economic nature (ESTELLÉS-AROLAS; GONZÁLEZLADRÓN-DE-GUEVARA, 2012).

The following terms are used in the literature in reference to VCI motivation mechanisms: "customer motivations/benefits" (NAMBISAN, 2002; FÜLLER, 2006), "rewarding mechanisms" (ROMERO; MOLINA, 2011), "offered incentives" (FÜLLER; MATZLER, 2007), "triggers for virtual customer integration" (FÜLLER; FAULLANT; MATZLER, 2010), "what the crowd gets in return” (ESTELLÉS-AROLAS; GONZÁLEZ-LADRÓNDE-GUEVARA, 2012).

\section{Organizer}

\subsection{Involvement-enabling entity}

The involvement-enabling entity - the organizer can be defined as that which will benefit from consumers' active participation, i.e., will benefit from their experience, knowledge, and ability to solve problems (ESTELLÉSAROLAS; GONZÁLEZ-LADRÓN-DE-GUEVARA, 2012). In short, the organizer is the entity benefiting from consumer input to NPD. An involvement-enabling entity is any given organization, institution, nonprofit organization or individual with the means to carry out the aforementioned initiative (ESTELLÉS-AROLAS; GONZÁLEZ-LADRÓNDE-GUEVARA, 2012). Romero and Molina (2011) claim that the organizer can be a group of organizations in collaborative networks, called "virtual organizations" (VO). These collaborative networks are formed in view of their 
complementary skills whenever a product development opportunity arises.

In the literature in question, the organizer is referred to as "crowdsourcer" and "initiator" (ESTELLÉSAROLAS; GONZÁLEZ-LADRÓN-DE-GUEVARA, 2012); "company" (FÜLLER; MATZLER, 2007); "firm" (SAWHNEY; VERONA; PRANDELLI, 2005); and "collaborative networked organization" and "virtual organization" (ROMERO; MOLINA, 2011).

\subsection{Return of involvement}

Return of involvement can be defined as the involvement enabler's benefit derived from getting involved virtually in NPD with consumers. Different types of return are reported in the literature on consumer involvement in NPD and are not specific to virtual involvement, such as those reported by Füller and Matzler (2007): reducing risks and market uncertainties, identifying unknown consumer needs, increasing the amount of product ideas, contacting potential consumers and retaining them, and increasing database of ideas for decision making. In short, the organization can benefit from the work, experience, and knowledge of those involved (ESTELLÉS-AROLAS; GONZÁLEZ-LADRÓNDE-GUEVARA, 2012). Moreover, Sawhney, Verona, and Prandelli (2005) reported benefits specific to virtual involvement, e.g., virtual consumer involvement tools allow: direct and/or mediated interactions with consumers, more frequent and real-time interactions, increased involvement endurance and speed, and increased audience size, i.e., number of involved consumers.

The following terms are used in the literature to refer to returns of involvement in VCI: "benefits of virtual customer integration" (FÜLLER; MATZLER, 2007); "what the initiator gets in return" (ESTELLÉS-AROLAS; GONZÁLEZ-LADRÓN-DE-GUEVARA, 2012).

\section{Virtual involvement process}

\subsection{Process-enabling tools}

VCI presupposes the use of tools for gathering consumer input. These tools can be defined as platforms that allow for interaction, dialogue, and gathering of consumer input by providing creative challenges or repetitive tasks, i.e., tasks of varying complexity aimed at solving problems (ESTELLÉS-AROLAS; GONZÁLEZ-LADRÓN-DEGUEVARA, 2012).

Virtual involvement-enabling tools consider computermediated communication (CMC) as a precipitous means. CMC consists of any type of interaction among geographically and temporally dispersed users by means of computers (NAMBISAN, 2002). However, as regards VCI, the literature refers specifically to the use of the Internet.
Evidence found in the literature in question is: "the medium used by crowdsourcing is the Internet" (ESTELLÉSAROLAS; GONZÁLEZ-LADRÓN-DE-GUEVARA, 2012); "the Internet as a platform for customer engagement" (SAWHNEY; VERONA; PRANDELLI, 2005), "interaction tools allow companies to gain valuable input from customers via the Internet" (FÜLLER; MATZLER, 2007).

The design/selection of tools should take into account the type of knowledge and experience of the consumer to be involved (ESTELLÉS-AROLAS; GONZÁLEZLADRÓN-DE-GUEVARA, 2012) and factors such as interaction frequency and input depth level (SAWHNEY; VERONA; PRANDELLI, 2005), multimedia richness level (FÜLLER et al., 2006), NPD stage in which consumers are to be involved (SAWHNEY; VERONA; PRANDELLI, 2005; FÜLLER; MATZLER, 2007), and involvement level (FÜLLER; MATZLER, 2007). These tools can be employed to gather input of consumers one by one in dyadic interactions with tools (FRANKE; KEINZ; SCHREIER, 2008) or groups of individuals, when the company's goal is to obtain social knowledge (SAWHNEY; VERONA; PRANDELLI, 2005).

VCI tools are referred to as "web-based methods of customer input" (DAHAN; HAUSER, 2002), "Internet based collaborative innovation mechanisms" (SAWHNEY; VERONA; PRANDELLI, 2005), "methods and tools of customer integration" (HEMETSBERGER; GODULA, 2007), "virtual interaction tools" (FÜLLER; MATZLER, 2007), and "mass customization toolkits" (FRANKE; KEINZ; SCHREIER, 2008).

Some VCI tools found in the literature are: information pump, web-based conjoint analysis, user design, fast polyhedral conjoint estimation, securities trading of concepts, and virtual concept testing (DAHAN; HAUSER, 2002); toolkits for user innovation (von HIPPEL; KATZ, 2002); listening in (URBAN; HAUSER, 2004); webbased asynchronous ideation (TOUBIA et al., 2004 apud HEMETSBERGER; GODULA, 2007); suggestion box, advisory panels, virtual communities, web-based idea markets, open-source mechanisms, web-based patent markets, online survey, marketing intelligence services, mass customization of the product, web-based prototyping, and virtual marketing testing (SAWHNEY; VERONA; PRANDELLI, 2005).

\subsection{Types of call}

The type of call refers to how consumers are brought into involvement in NPD. Füller and Matzler (2007) indicate that the organization should clearly specify the profile and segment of consumers to be involved and then identify them and bring them into specific virtual communities. E-mails, banners, advertisements on websites, for instance, can be used for the call, which can be done via a trusted 
intermediary member of the community (FÜLLER et al., 2006). Romero and Molina (2011) report that the VCI call should be preceded by the selection of appropriate criteria to identify consumers who can actually contribute and who have complementary skills. On the other hand, Estellés-Arolas and González-Ladrón-de-Guevara (2012) state that this call should be flexible and take either one of the following forms (WHITLA, 2009, apud ESTELLÉSAROLAS; GONZÁLEZ-LADRÓN-DE-GUEVARA, 2012): (1) open call to anyone interested in participating, and (2) open call, but with control of those who can participate based on their expertise and knowledge.

The VCI call can be found in the literature as: "cocreators targeting" (ROMERO; MOLINA, 2011), "user access and participation" (FÜLLER et al., 2006), and "call” (ESTELLÉS-AROLAS; GONZALÉZ-LADRÓNDE-GUEVARA, 2012).

\subsection{Trigger}

Trigger is the process initiator, the motivation for VCI. Given that the VCI process results in an alliance, i.e., a collaborative network of organizations and individuals, a trigger can be referred to as the best way to accomplish shared or compatible goals (CAMARINHA-MATOS; AFSARMANESH, 2008). Shared or compatible goals, which could hardly be achieved in isolation, are referred to by other authors as triggers to "develop innovations" (von HIPPEL, 2005), "value co-creation" (ROMERO; MOLINA, 2011), and "resolution of the problem" (ESTELLÉSAROLAS; GONZALÉZ-LADRÓN-DE-GUEVARA, 2012).

\section{Final remarks}

This study presents the result of an exploratory literature review conducted in order to provide a consistent characterization of VCI in NPD in light of seminal and relevant studies carried out in different areas. Seven constructs were identified and categorized into three groups. The first group consists of constructs typifying consumers and their motivations to get virtually involved. The second group consists of constructs typifying organizers and their motivations in promoting VCI. The third group consists of constructs characterizing the VCI process, thereby indicating tools, types of consumer involvement calls, media used for this purpose, and VCI triggers.

Construct identification and characterization constitute the first step to generating an understanding, a working definition of VCI in NPD, consistent with distinct approaches from different areas. These constructs allude to key terms used in the context of VCI, which may contribute to the establishment of keywords and search strings, the definition of strategies for conducting a systematic literature review, and the development of an integrated and operational definition of this subject.

\section{References}

BRABHAM, D. C. Crowdsourcing as a model for problem solving: an introduction and cases. Convergence: The International Journal of Research into New Media Technologies, v. 14, n. 1, p. 75-90, 2008. http://dx.doi. org/10.1177/1354856507084420

CAMARINHA-MATOS, L. M.; AFS ARMANESH, H. On reference models for collaborative networked organizations. International Journal of Production Research, v. 46, n. 9, p. 2453-2469, 2008. http://dx.doi. org/10.1080/00207540701737666

CICCANTELLI, S.; MAGIDSON, J. From experience: consumer idealized design: involving consumers in the product development process. Journal of Product Innovation Management, v. 10, n. 4, p. 341-347, 1993. http://dx.doi.org/10.1016/0737-6782(93)90076-3

DAHAN, E.; HAUSER, J. R. The virtual customer. Journal of Product Innovation Management, v. 19, p. 332-353, 2002. http://dx.doi.org/10.1016/S0737-6782(02)00151-0

ESTELLÉS-AROLAS, E.; GONZÁLEZ-LADRÓN-DEGUEVARA, F. Towards na integrated crowdsourcing definition. Journal of Information Science, v. 38, n. 2, p. 189200, 2012. http://dx.doi.org/10.1177/0165551512437638

FRANKE, N.; KEINZ, P.; SCHREIER, M. Complementing mass customization toolkits with user communities: how peer input improves customer self-design. Journal of Product Innovation Management, v. 25, p. 546-559, 2008. http://dx.doi.org/10.1111/j.1540-5885.2008.00321.x

FÜLLER, J. Why consumers engage in virtual new product developments initiated by producers. Advances in Consumer Research, v. 33, p. 639-646, 2006.

FÜLLER, J. et al. Community based innovation: how to integrate members of virtual communities into new product development. Eletronic Commerce Research Journal, v. 6, n. 1, p. 57-73, 2006. http://dx.doi.org/10.1007/s10660006-5988-7

FÜLLER, J.; FAULLANT, R.; MATZLER, K. Triggers for virtual customer integration in the development of medical equipment - from a manufacturer and a user's perspective. Industrial Marketing Management, v. 39, p. 1376-1383, 2010. http://dx.doi.org/10.1016/j. indmarman.2010.04.003

FÜLLER, J.; MATZLER, K. Virtual product experience and customer participation - a chance for customer-centred, really new products. Technovation, v. 27, p. 378-387, 2007. http://dx.doi.org/10.1016/j.technovation.2006.09.005 
GONZÁlezZ, M. O. A.; TOLEDO, J. C. A integração do cliente no processo de desenvolvimento de produto: revisão bibliográfica sistemática e temas para pesquisa. Produção, v. 22, n. 1, p. 14-26, 2012. http://dx.doi.org/10.1590/S010365132011005000065

GRUNER, K. E.; HOMBURG, C. Does customer interaction enhance new product success? Journal of Business Research, v. 49, p. 1-14, 2000. http://dx.doi.org/10.1016/ S0148-2963(99)00013-2

HEMETSBERGER, A.; GODULA, G. Virtual customer integration in new product development in industrial markets: the QLL framework. Journal of Business-toBusiness Marketing, v. 14, n. 2, p. 1-40, 2007. http://dx.doi. org/10.1300/J033v14n02_01

KOHLER, T. et al. Avatar-based innovation: consequences of the virtual co-creation experience. Computers in Human Behavior, v. 27, p. 160-168, 2011. http://dx.doi. org/10.1016/j.chb.2010.07.019

LETTL, C. User involvement competence for radical innovation. Journal of Engineering and Technology Management, v. 24, p. 53-75, 2007. http://dx.doi. org/10.1016/j.jengtecman.2007.01.004

NAMBISAN, S. Designing virtual customer environments for new product development: toward a theory. Academy of Management Review, v. 27, n. 3, p. 392-413, 2002.

NAMBISAN, P.; WATT, J. H. Managing customer experiences in online product communities. Journal of Business Research, v. 64, p. 889-895, 2011. http://dx.doi. org/10.1016/j.jbusres.2010.09.006

PLANT, R. Online communities. Technology in Society, v. 26, p. 51-65, 2004. http://dx.doi.org/10.1016/j. techsoc.2003.10.005
PRAHALAD, C. K.; RAMASWAMY, V. Co-creation experiences: the next practice in value creation. Journal of Interactive Marketing, v. 18, n. 3, 2004. http://dx.doi. org/10.1002/dir.20015

ROHRBECK, R.; STEINHOFF, F.; PERDER, F. Sourcing innovation from your customer: how multinational enterprises use web platforms for virtual customer integration. Technology Analysis \& Strategic Management, v. 22, n. 2, p. 117-131, 2010. http://dx.doi. org/10.1080/09537320903498462

ROMERO, D.; MOLINA, A. Collaborative networked organisations and customer communities: value co-creation and co-innovation in the networking era. Production Planning \& Control, p. 1-26, 2011.

SAWHNEY, M.; VERONA, G.; PRANDELLI, E. Collaborating to create: the internet as a platform for customer engagement in product innovation. Journal of Interactive Marketing, v. 19, n. 4, 2005. http://dx.doi.org/10.1002/dir.20046

SAWHNEY, M.; PRANDELLI, E. Communities of creation: managing distributed innovation in turbulent markets. California Management Review, v. 42, n. 4, 2000. http:// dx.doi.org/10.2307/41166052

THOMKE, S.; VON HIPPEL, E. Customers as innovators: a new way to create value. Harvard Business Review, 2002.

URBAN, G. L.; HAUSER, J. R. Listening in to find and explore new combinations of customer needs. Journal of Marketing, v. 68, p. 72-87, 2004. http://dx.doi.org/10.1509/ jmkg.68.2.72.27793

VON HIPPEL, E. Democratizing innovation. Cambridge: MIT Press, 2005.

VON HIPPEL, E.; KATZ, R. Shifting innovation to users via toolkits. Management Science, v. 48, n. 7, p. 821833, 2002. http://dx.doi.org/10.1287/mnsc.48.7.821.2817 